\title{
Localization of striatal excitatory amino acid binding site subtypes to striatonigral projection neurons
}

\author{
Sara J. Tallaksen-Greene ${ }^{a}$, Ronald G. Wiley ${ }^{b}$ and Roger L. Albin ${ }^{a}$ \\ a Department of Neurology, University of Michigan, Ann Arbor, MI (USA) \\ and 'Departments of Neurology and Pharmacology, DVAMC and Vanderbilt University, Nashville, TN (USA)
}

(Accipted 21 July 1992)

Key words: Striatum; Excitatory amino acid; Striatonigral projection; $N$-methyl-D-aspartate (NMDA); Volkensin

\begin{abstract}
Quantitative autoradiography was used to examine the cellular localization of excitatory amino acid binding sites in the striatum following selective lesion of striatonigral projection neurons. Degeneration of striatonigral neurons was induced unilaterally by injection of the suicide transport toxin, volkensin, into the left substantia nigra. Twelve days following nigral volkensin injection there was a reduction of all excitatory amino acid binding site subtypes in the striatum ipsilateral to the injected nigra. The reduction in $N$-methyl-D-aspartate (NMDA) binding sites was significantly greater than the loss of D,L- $\alpha$-amino-3-hydroxy-5-methylisoxazole-4-proprionic acid (AMPA), kainate and metabotropic binding. These results indicate that there are NMDA, AMPA, metabotropic and kainate binding sites on striatonigral projection neurons and suggest that the NMDA subtype may be selectively enriched on striatonigral neurons.
\end{abstract}

The main afferent component of the basal ganglia is the striatum, which receives a massive cortical projection thought tc be excitatory amino acidergic (EAAergic)'. EAAs act on at least four subtypes of EAA receptors classified on the basis of their pharmacological properties into $N$-methyl-D-aspartate (NMDA), D,L- $\alpha$-amino-3-hydroxy-5-methylisoxazole-4proprionic acid (AMPA), metabotropic (MET) and kainate (KA) receptors ${ }^{34}$. Autoradiographic studies have identified high levels of all of these EAA receptor subtypes within the striatum'. Although it has been suggested that there are presynaptic EAA receptors in the striatum ${ }^{8,11}$, the majority of striatal EAA binding sites appear to be localized post-synaptically on striatal neurons ${ }^{14}$. Anatomical studies have shown that the striatum is composed predominently of output neurons $^{25}$. Two major populations of striatal projection neurons have been characterized on the basis of target structure; globus pallidus (GP) and substantia nigra $(\mathrm{SN})^{12,21,22,26}$. However, the localization of EAA receptor subtypes to specific populations of striatal neurons has not been determined. In the present study, we used a suicide transport toxin, volkensin, to destroy striatonigral projection neurons in a fashion similar to Harrison et al. ${ }^{18}$. Following volkensin injection into the $\mathrm{SN}$, we used quantitative autoradiography to examine the localization of EAA binding site subtypes in the rat forebrain.

Volkensin was prepared from Adenia volkensii as previously described ${ }^{31}$. Unilateral injections of the toxin (0.5-0.8 ng in 0.025-0.04 $\mu$ l 0.1 M PBS, pH 7.4,+0.1\% Fast green) were made into the left SN of 6 adult, male Sprague-Dawley rats (195-260 g; Spartan Labs, Hastings, MI). Stereotaxic coordinates, determined using the rat atlas of Paxinos and Watson ${ }^{27}$, were $5.4 \mathrm{~mm}$ posterior to bregma, $1.8 \mathrm{~mm}$ to the left of the superior saggital suture and $8.2 \mathrm{~mm}$ ventral to the surface of the skull. Following a survival period of 12 days, the animals were sacrificed by decapitation, their brains were rapidly removed, frozen in powdered dry ice and stored at $-70^{\circ} \mathrm{C}$ until use. $20-\mu \mathrm{M}$ sections were cut using a cryostat microtome, thaw-mounted onto gelatin-coated slides and stored at $-20^{\circ} \mathrm{C}$ for $24-48 \mathrm{~h}$. Serial sections of the striatum were processed for EAA autoradiogra- 

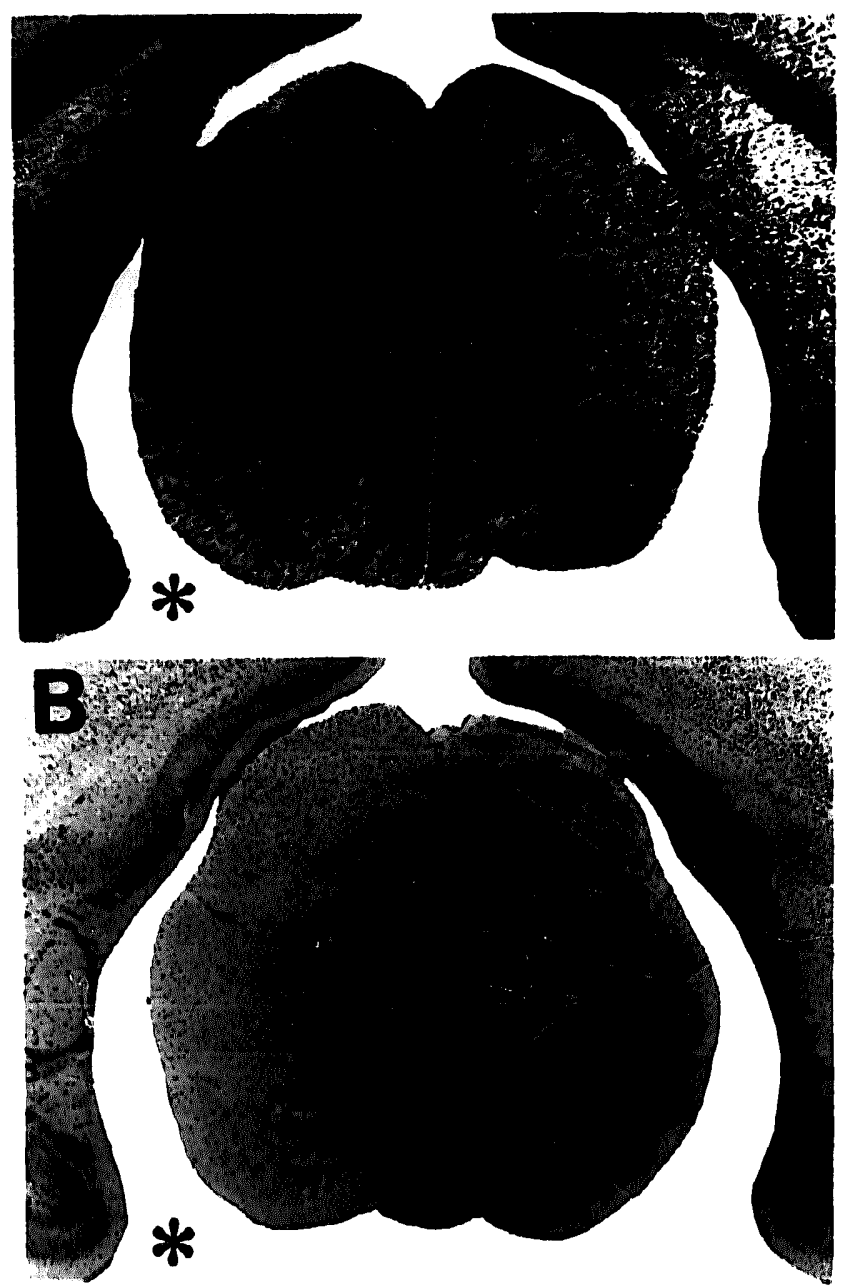

Fig. 1. Effects of volkensin lesion on the substantia nigra. The usterisk indieates the side ipsilateral to the volkensin injection. $A_{i}$ autoradiogram demonstrating total binding of ['H]SCH 23390 to $\mathrm{D}_{1}$ receptors in the substantia nigra. B: photomicrograph of a section

laken from the same animal and stuined with Cresyl violet.

phy. Dopamine receptor autoradiography and Cresyl violet staining were used to examine sections of the the substantia nigra.

The autoradiographic assays for EAA and $D_{1}$ receptor binding sites were performed using previously de-

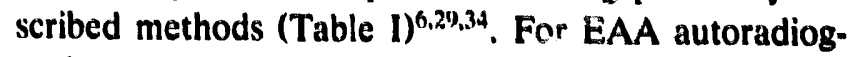
saphy, sections were prewashed in buffer for $30 \mathrm{~min}$ at $4^{\circ} \mathrm{C}$ and dried under a stream of warm air prior to a 45 min incubation in ice-cold buffer containing radioligand and the appropriate blocking agents. The binding reaction was terminated by rapidly rinsing each slide with 4 squirts of buffer $\left(4^{\circ} \mathrm{C}\right)$ followed by 2 squirts of cold $2.5 \%$ gluteraldehyde in acetone, and drying the sections under a stream of hot air. $D_{1}$ receptor binding sites were assayed using the method of Richfield et al. ${ }^{29}$ (Table I). Sections were incubated in ligand solution for $180 \mathrm{~min}$ at room temperature, rinsed in buffer $\left(10 \mathrm{~min}, 4^{\circ} \mathrm{C}\right.$ ), dipped in ice-water and dried under a stream of hot air. The slides were apposed to tritiumsensitive film (Hyperfilm, Amersham) and exposed for 1-2 weeks with known radioactive standards. The autoradiograms were analyzed using a computer-assisted densitometry program (MCID system, Imaging Research, St. Catharine's, Ont., Canada). For each animal, all regions were analyzed in triplicate and specific binding was determined by subtracting non-specific from specific binding. EAA receptor subtypes were measured in the striatum, cerebral cortex and nucleus accumbens. For purpose of analysis, the striatum was divided into quandrants; dorsolateral (STR dl), dorsomedial (STR dm), ventromedial (STR vm) and ventrolateral (STR vl), and the cerebral cortex was divided into superficial (I-III; Cx out) and deep (IV-VI; Cx in) layers. Analysis of EAA binding data was performed using the SAS computer program (SAS Institute, Cary, NC, USA). For each ligand (Fig. 2), repeated measures ANOVA on two factors (region and treatment) was used to compare binding densitics ipsilateral and contralateral to the lesion. The Bonferroni method of multiple comparisons was used to control for the overall (family-wise) error rate at alpha $=0.05$. For each region (Table III), the ratio of ipsilateral to contralateral binding densities of the different EAA binding sites were compared using a one-way ANOVA followed by a Scheffé post-hoc F-test. The substantia nigra was examined using Cresyl violet stain to evaluate lesion placement and $D_{1}$ receptor autoradiography to assess striatonigral degeneration ${ }^{18}$. $D_{1}$ binding data was analyzed with a paired Student's $t$-test (significance level $=P<0.05$ ).

Histological examination of the volkensin injection site revealed an area of cell loss and gliosis within the SN (Fig. 1B). $D_{1}$ binding in the $S N$ was profoundly reduced (>90\%) following volkensin injection (Fig. 1A, Table II). The effects of nigral volkensin injection on EAA binding site subtypes are shown in Fig. 2 and Table III. Analysis of variance indicated that in most

Fig. 2. Effect of nigral volkensin on EAA receptor binding in the forebrain. $\left[{ }^{3} \mathrm{H}\right]$ glutamate binding, (B) $\left[{ }^{3} \mathrm{H}\right]$ AMPA binding, (C) $\left[{ }^{3} \mathrm{H}\right]$ glutamate binding to the metabotropic site and (D) $\left[{ }^{3} \mathrm{H}\right] \mathrm{kain}$ (otal (A) NMDA-sensitive indicates the side ipsilateral to volkensin injection. Right panel: histograms comparing specific binding on the control side (solid bars) to specific binding on the lesion side (hatched bars). Cx out, superficial (I-III) frontoparietal cortex; Cx in, deep (IV-VI) frontoparietal cortex; STR dl, dorsulateral striatum; STR dm, dorsomedial striatum; STR vm, ventromedial striatum; STR vl, ventrolateral striatum; Acc, nucleus accumbens. Statistical significance was determined using repeated measures ANOVA on two factors (region and treatment) with a Bonferroni correction for multiple comparisons $(* \alpha=0.05, * * \alpha=0.01)$ 

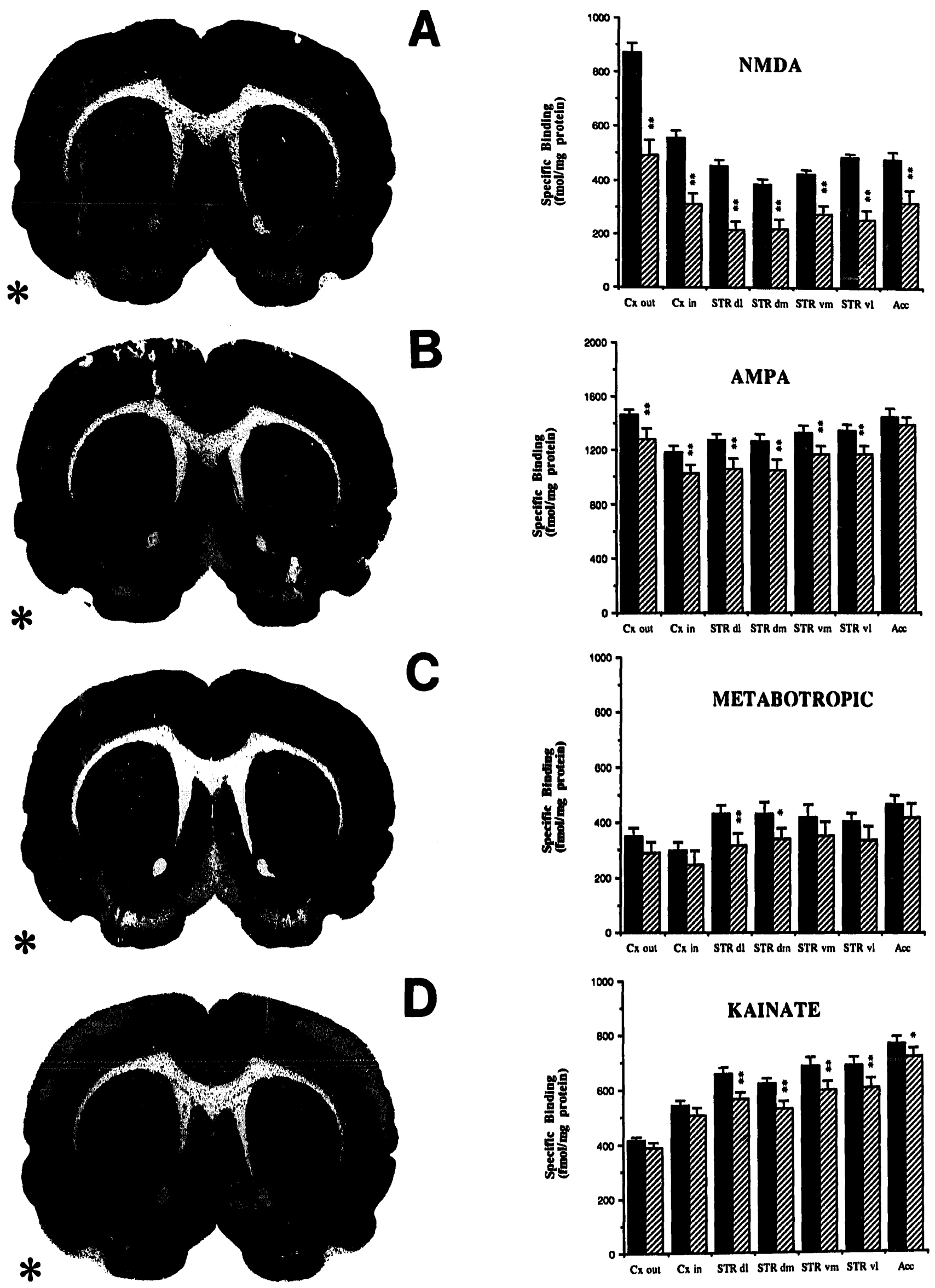
TABLE I

EAA and $D_{1}$ binding sitc assays

\begin{tabular}{|c|c|c|c|c|c|c|}
\hline Binding sike & Ligand & Specific actitity & Conc. & Buffer & Blockers & Blank \\
\hline$\overline{\text { NMDA }}$ & {$\left[{ }^{3} \mathrm{H}\right]$ Glutamate } & $50 \mathrm{Ci} / \mathrm{mmol}$ & $65 \mathrm{nM}$ & $\begin{array}{l}50 \mathrm{mM} \text { Tris-acetate } \\
\text { pH } 7.4,4^{\circ} \mathrm{C}\end{array}$ & $\begin{array}{l}2.5 \mu \mathrm{M} \text { quisqualate }+ \\
1 \mu \mathrm{M} \text { kainate }\end{array}$ & $1 \mathrm{mM}$ NMDA \\
\hline Kainate & {$\left[{ }^{3} \mathrm{H}\right]$ Kainate } & $58 \mathrm{Ci} / \mathrm{mmol}$ & $60 \mathrm{nM}$ & $\begin{array}{l}50 \mathrm{mM} \text { Tris-acetate } \\
\mathrm{pH} 7.4,4^{\circ} \mathrm{C}\end{array}$ & & $100 \mu \mathrm{M}$ kainate \\
\hline AMPA & {$\left[{ }^{3} \mathrm{H}\right] \mathrm{AMPA}$} & $60 \mathrm{Ci} / \mathrm{mmol}$ & $16 \mathrm{nM}$ & $\begin{array}{l}50 \mathrm{mM} \text { Tris } \cdot \mathrm{HCl}+ \\
2.5 \mathrm{mM} \mathrm{CaCl} \\
30 \mathrm{mM} \mathrm{KSCN}^{+} \\
\mathrm{pH} 7.2,4^{\circ} \mathrm{C}\end{array}$ & & $1 \mu \mathrm{M}$ glutamate \\
\hline Metabotropic & {$\left[{ }^{3} \mathrm{H}\right]$ Glutamate } & $50 \mathrm{Ci} / \mathrm{mmol}$ & $100 \mathrm{nM}$ & $\begin{array}{l}50 \mathrm{mM} \text { Tris- } \mathrm{HCl}+ \\
2.5 \mathrm{mM} \mathrm{CaCl}_{2}+ \\
30 \mathrm{mM} \mathrm{KSCN}^{+} \\
\mathrm{pH} 7.2 .4^{\circ} \mathrm{C}\end{array}$ & $\begin{array}{l}100 \mu \mathrm{M} \text { NMDA + } \\
10 \mu \mathrm{M} \text { AMPA }\end{array}$ & $5 \mu \mathrm{M}$ quisqualate \\
\hline$D_{1}$ & ['H]SCH 23390) & $8.3 \mathrm{Ci} / \mathrm{mmol}$ & $0.55 \mathrm{nM}$ & $\begin{array}{l}25 \mathrm{mM} \text { Tris- } \mathrm{HCl}+ \\
100 \mathrm{mM} \mathrm{NaCl} \\
100 \mathrm{mM} \mathrm{MgCl} \\
1 \mu \mathrm{M} \text { pargyline }+ \\
0.001 \% \text { ascorbate } \\
\text { pH 7.5, R.T. }\end{array}$ & & $1 \mu \mathrm{M}$ cis-flupentixol \\
\hline
\end{tabular}

\section{TABLE II}

D, binding in the substantia nigra following toolkensin injection

Ditta is expressed as specific hinding in $\mathrm{fmol} / \mathrm{mg}$ tissue (mean \pm S.E.M.), $\| \approx$ 6. Percentinge, (ipsilateral/contralateral) $\times 10(0)$ " ${ }^{*}$ Statislically different from control side (paired t-test. $P<(0,00()) 1$ ). No significiunt difference between medial $S N$ and lateral SN (1-way ANOVA. Schéffe's F-lest).

\begin{tabular}{|c|c|c|c|}
\hline Rexion) & C'ontrol side' & Lesiom side & Porcinllage \\
\hline Medial SN & $1.281) \pm 4.3$ & 55 出 31$)^{*}$ & $4.2 \%$ \\
\hline Lateral SN & $1.301+35$ & $99 \pm 6.3$ * & $7.6 \%$ \\
\hline
\end{tabular}

regions examined, loss of NMDA binding sites was significantly greater than the loss of AMPA, metabotropic or kainate binding sites (Table III, $P$ $<0.05)$. In striatum, volkensin injection into the nigra reduced NMDA binding by approximately $50 \%$. The other EAA binding site subtypes exhibited more modest reductions; up to $18 \%$ for AMPA, 27\% for MET and $15 \% \mathrm{KA}$. Nigral volkensin injection significantly reduced NMDA and KA binding in nucleus accumbens (35\% and 7\%, respectively). The reductions in AMPA and MET binding in nucleus accumbens were not significant. In cerebral cortex, nigral volkensin reduced binding to the NMDA site nearly $45 \%$ and binding to the AMPA site almost 15\%; changes in MET and KA binding were not statistically significant.

Our results indicate that there are NMDA, KA, AMPA and MET EAA binding sites on striatonigral projection neurons. These findings are consistent with electrophysiological ${ }^{7.21}$ and lesion ${ }^{10,11,14,16,31)}$ studies that suggest that striatal EAA binding sites are located predominantly on striatal neurons.

\section{TABLEE III}

Comparison of percent differences in specific binding following rolkensin injection into the substantia nigra

Data is expressed as specific binding (ipsilateral/contralateral) $\times 100$ ). For each region, the ratio of ipsilateral to contralateral binding densities of the different EAA binding sites were compared using a one factor ANOVA followed by i Scheffe F-lest. In most regions, loss of NMDA binding sites was greater than the loss of other EAA binding sites. * Significant difference in the decrease of AMPA. MET or KA binding compared to NMDA hinding. $\boldsymbol{P}<0.05$. There were no significant differences between binding to the AMPA, MET and KA sites. Cx out, superficial (I-III) fromtoparietal cortex: $C x$ in. deep (IV-VI) frontoparietal cortex; STR di, dorsolateral striatum; STR dm, dorsomedial striatum; STR vm, ventromedial striatum: STR vl, ventrolateral striatum; Acc, nucleus accumbens.

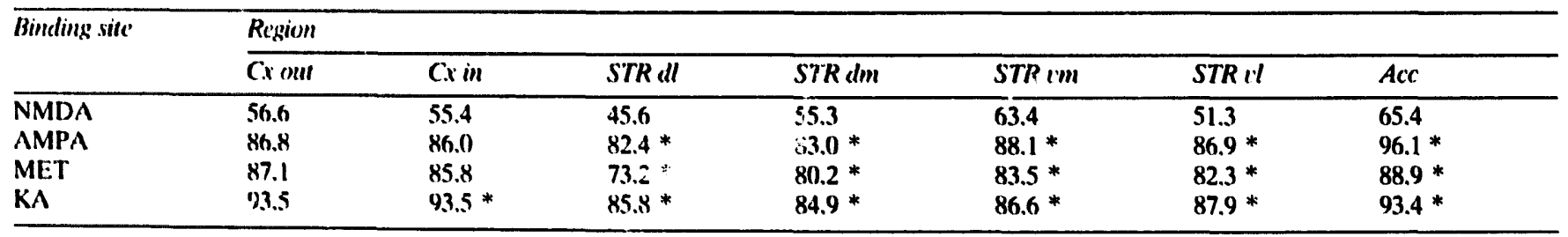


The relative magnitude of changes in striatal EAA binding that we observed following volkensin injection into the SN suggests that NMDA binding sites are enriched on striatonigral neurons. In addition to NMDA binding sites, striatonigral neurons have been shown to selectively express $D_{1}$ receptors on both cell bodies $^{18}$ and nerve terminals ${ }^{4}$. Interestingly, NMDA receptor activation and $D_{1}$ receptor activation have been shown to have opposite effects on the phosphorylation of DARPP-32, a neuronal phosphoprotein highly enriched in striatonigral neurons ${ }^{17,23}$. Dopamine appears to differentially regulate the production of neuropeptides and the activity of striatonigral and striatopallidal neurons. The basis of the differential regulation of striatal projection neurons may be, in part, the selective expression of $D_{1}$ and $D_{2}$ receptor subtypes $^{2.13}$. Our data is consistent with the hypothesis that differential distribution of EAA receptor subtypes may also be important in the regulation of projection neuron subpopulations.

Heterogeneous distribution of EAA binding sites within the rat striatal complex has been previously reported'. In the present study, we observed a heterogeneous distribution of changes induced by nigral volkensin injection. For example, NMDA binding was reduced ipsilateral to the lesion in all regions examined, whereas binding to the metabotropic site was decreased only in the dorsal striatum. Similarly, changes in binding to the different EAA receptor subtypes were inhomogeneous among regions. For example, in nucieus accumbens, nigral volkensin injection reduced NMDA and KA binding while binding to the AMPA and MET receptor subtypes was not significantly changed. These results suggest differential distribution of EAA binding site subtypes among striatal and nucleus accumbens neurons projecting to the $S N^{15,11}$.

Our findings suggest that there may be EAA binding sites on corticonigral neurons. Since all neurons projecting to SN may be susceptible to the toxic effects of volkensin, direct projections from the cerebral cortex ${ }^{3.5}$ may account for assymmetries in EAA binding in cerebral cortex induced by nigral volkensin injection. Alternatively, EAA binding site changes may be due to trans-synaptic degeneration induced by loss of striatal neurons that are recipients of cortical afferents.

There are several points to consider regarding possible limitations of the experimental paradigm used in this study. Volkensin has local toxic effects ${ }^{9,24,33}$, and in the present study, we noted a restricted area of cell loss at the site of injection (Fig. 1B). It is unlikely, however, that the changes we observed in striatal EAA binding were due to anterograde degeneration of nigrostriatal neurons (which are largely dopaminergic), since previous studies have reported that 6-hydroxydopamine lesion of nigrostriatal neurons have no affect on binding to striatal EAA receptors ${ }^{10,11,16}$. Leakage of volkensin from target neurons has been shown to occur with excessive doses ${ }^{32}$. The question of trans-synaptic transfer of volkensin has been raised ${ }^{33}$, but not proven. In the present study, it is possible that the reduction we observed in cortical EAA receptors following nigral volkensin injection may be due, at least in part, to degeneration of corticonigral neurons induced by the release of volkensin from striatal neurons. However, it is unlikely that corticostriatal neuron degeneration, if it did occur, could account for the changes we observed in striatal EAA binciing sites since decortication has generally been shown to have little affect on the density of striatal EAA receptors ${ }^{10,14,30}$. One exception, which is contradicted by the results of Greenamyre and Young ${ }^{14}$, is a report by Errami and Nieuollen"1 describing a $30 \%$ decrease in $\left[{ }^{3} \mathrm{H}\right] \mathrm{AMPA}$ binding following decortication. Finally, it has been reported that volkensin may spread from the site of injection'. In our study, histological examination did not reveal any volkensin-induced changes outside the boundaries of the SN. However, it is possible that the decrease we observed in NMDA and KA receptor binding sites in nucleus accumbens may be due to degeneration of neurons in nucleus accumbens projecting to regions surrounding the $\mathrm{SN}$, such as the ventral tegmental area. In the present study, we have used volkensin in combination with quantitative autoradiography to characterize EAA receptor subtypes in relation to striatonigral neurons. Our results are the first to characterize EAA receptor subtypes in relation to a specific population of striatal projection neurons.

Th s work was supported by NS 01300), NS 19613 and the Hereditary Dis ase Foundation. The authors would like to thank Dr. Roy T. St. Laurent for help with the statistical analysis.

, Albin, R.L., Makowiec, R.L., Hollingsworth, Z.R., Dure, L.S., IV, Penney Jr., J.B. and Young, A.B., Excitatory amino acid binding siles in the basal ganglia of the rat: a quantitative aut(radiographic study, Neuroscience. 46 (1992) 35-48.

$\therefore$ Albin, R.L., Young, A.B. and Penney, J.B., The functional anatomy of basal ganglia disorders, Trends Neurosci., 12 (1989) 366-375.

3 Beckstead, R.M., An autoradiographic examination of corticocortical and subcortical projections of the mediodorsal projection (jucfrontal) cortex in the rat, J. Comp. Neurol., 184 (1979) 4.3-62.

4 Black, M.D. and Crossman, A.R., Changes in dopamine $D_{1}$ and $D_{2}$ receptor binding in the substantia nigra following intrastriatal injection of a retrograde neurotoxin (volkensin), Neurosci. Lett., 134 (1992) 180-182.

5 Bunney, B.S. and Aghajanian, G.K., The precise localization of nigral afferents in the rat as determined by a retrograde tracing technique, Brain Res., 117 (1976) 423-435.

6 Cha, J.J., Makoweic, R.L., Penney Jr., J.B. and Young, A.B., L. $\left[{ }^{3}\right.$ H]Glutamate labels the metabotropic excitatory amino acid receptor in rodent brain, Neurosci. Lett., 113 (1990) 78-83. 
7 Cherubini. E.. Herrling, P.L., Lanfumey, L. and Stanzione, P. Excitatory amino acids in synaptic excitation of rat striatal neurones in vitro, J. Physiol., 400 (1988) 677-690.

8 Chéramy, A., Romo, R. and Glowinski. J.. The relative roles of neuronal activity and direct presynaptic mechaslisms in controlling the release of dopamine from the cat ciludate nucleus, $A n n$. N.Y. Acad. Sci. (1990) 80-91.

9 Contestabile, A., Fasolo, A., Virgili, M., Migani, P., Villani, L. and Stirpe, F.. Anatomical and neurochemical evidence for suicide transport of a toxic lectin, volkensin, injected in the rat dorsal hippocampus, Brain Res., 537 (1990) 279-286.

10 Errami. M. and Nieoullon, A., Development of a micromethod to study the $\mathrm{Na}^{+}$-independent $\mathrm{L}-\left[{ }^{3} \mathrm{H}\right]$ glutamic acid binding to rat striatal membranes. Il. Effects of selective striatal lesions and deafferentations, Brain Res., 366 (1986) 178-186.

11 Errami. M. and Nieoullon, A., $\alpha-\left[{ }^{3} \mathrm{H}\right]$ Amino-3-hydroxy-5-methyl4-isoxazolepropionic acid binding to rat striatal membranes: effects of selective brain lesions. J. Neurochem., 51 (1988) 579-586.

12 Férger. J. and Crossman. A.R.. Identification of different subpopulations of neostriatal neurones projecting to globus pallidus or substantia nigra in the monkey: a retrograde fluorescence double-labelling study, Neurosci. Lett. 49 (1984) 7-12.

13 Gerfen. C.R., Engber. T.M., Mahan, L.C., Susel, Z., Chase, T.N., Monsma Jr., F.J. and Sibley, D.R., $D_{1}$ and $D_{2}$ dopamine receptor-regulated gene expression of striatonigral and striatopallidal neurons. Science. 250 (1990) 1429-1432.

14 Greenamyre, J.T. and Young. A.B., Synaptic localization of striatal NMDA. quisqualate and kainate receptors. Neurosci. Lett. $101(1989)$ 1.33-1.37.

15 Groenewegen. H.J. and Russchen, F.T., Organization of the efferent projections of the nucleus accumbens to pallidal, hypothalamic, and mesencephalic structures: a tracing and immuno. histochemical study in the cat. J. Comp. Neurol., 223 (1984) 347-367.

16 Gundlach, A.L., Largent, B. and Snyder, S.H., Phencyclidine (PCP) receptors: autoradiographic localization in brain with the selective ligand. ['H)TCP. Brain Res., 3\%6 (1986) 206-270).

17 Ilalpain. S.. Girault, J.A. and Greengard, P., Activation of NMDA receptors induces dephosphorylation of DARPP.32 in rat striatal slices, Nanure, 34,3 (1940) 369-372.

Is Harrison, M.B., Wiley, R.G. and Wooten, G,F., Selective locul. iantion of striatal $D_{1}$ receptors to striatonigral neurons, Brain $R(s, 528(190)() ! 317-322$

19 Heimer. L., Zihm, D.S., Churchill, L., Kallivas, P.W. and Wohlt. mann. C.. Specificity in the projection patterns of accumbul core and shell in the rat. Neurescience, 41 (1991) 89-125.

20) Herrling. P.L., Morris, R. and Salt, T.E.. Effects of excitatory amino acids and their antagonists on membrane action potentials of cal caudate neurones, J. Physiol., 339 (1983) 2017-222.
21 Kawaguchi, Y., Wilson, C.W. and Emson, P.C., Projection subtypes of rat neostriatal matrix cells revealed by intracellular injection of biocytin, J. Neurosci., 10 (1990) 3421-3438.

22 Loopuijt, L.D. and Van der Kooy, D., Organization of the striatum: collateralization of its efferent axons, Brain Res., 348 (1985) 86-89.

23 Nairn, A.C., Hemmings Jr., H.C., Walaas S.I. and Greengard, P., DARPP-32 and phoshatase inhibitor-1, two structurally related inhibitors of protein phosphatase-1, are both present in striatonigral neurons, J. Neurochem., 50 (1988) 257-262.

24 Pangalos, M.N., Francis, P.T., Pearson, R.C.A, Middlemiss, D.N. and Bowen, D.M., Destruction of a sub-population of cortical neurones by suicide transport of volkensin, a lectin from Adenia rolkensii, J. Neurosci. Methods, 40 (1991) 17-29.

25 Parent, A., Extrinsic connections of the basal ganglia, Trends Neurosci., 13 (1990) 254-258.

26 Parent, A., Bouchard, C. and Smith, Y., The striatopallidal and striatonigral projections: two distinct fiber systems in primate, Neurosci. Lett., 96 (1989) 140-144.

27 Paxinos, G. and Watson, C., The Rat Brain in Stereotaxic Coordinates, Academic Press, Orlando, 1986.

28 Porceddu, M.L., Giorgi, O., De Montis, G., Meles, S., Cocco, L., Ongini, E. and Biggio, G., 6-Hydroxydopamine-induced degeneration of nigral dopamine neurons: differential effect on nigral and striatal D-1 dopamine receptors, Life Sci. 39 (1986) 321-328.

29 Richfield, E.K., Young, A.B. and Penney Jr, J.B., Comparative distribution of dopamine $D_{-}$and $D_{-2}$ receptors in the basal ganglia of turtles, pigeons, rats, cats and monkeys, J. Comp. Neurol., 262 (1987) 446-463.

30 Roberts, P.J., McBean, G.J., Sharif, N.A. and Thomas, E.M., Striatal glutamatergic function: modifications following specific lesions, Brain Res., 235 (1982) 83-91.

31 Stirpe, F., Barbieri, L., Abbondonza, A., Falasca, A.l., Brown, A.N.F., Sandvig, K., Olsnes, S. and Pihl, A., Properties of volkensin, a toxic lectin from Adenia tolkensii, J. Biol. Chem., 2(1) (1985) 14589-14595.

32 Wiley, R.G, and Stirpe, F, Neuronotoxicity of axonally transported toxic lectins, abrin, modeccin and volkensin in rat peripheral nervous system, Neuropathol. Appl. Neurobiol., 12 (1986) $39-53$.

33 Wiley, R.G. und Stirpo, F., Modecein and volkensin but not abrin are effective suicide transport agents in rat CNS, Brain Res., 438 (1988) 145-154

34 Young, A.B, und Fugg, G.E., Excitutory amino acid receptors in the brain: membrane binding and receptor autoradiographic approaches, Trends Pharmacol. Sci., 11 (1990) 126-133. 